\title{
Innovations in the teaching-learning process of psychiatric nursing and mental health
}

\author{
As inovações no processo ensino-aprendizagem da enfermagem psiquiátrica e saúde mental \\ Innovaciones en el proceso de enseñanza-aprendizaje de enfermería psiquiátrica y salud mental
}

'Universidade Federal Fluminense. Niterói, Rio de Janeiro, Brazil.

"Universidade Federal do Rio de Janeiro, Instituto de Biodiversidade e Sustentabilidade. Macaé, Rio de Janeiro, Brazil.

How to cite this article:

Tavares CMM, Pastor Junior AA, Paiva LM, Lima TO. Innovations in the teaching-learning process of psychiatric nursing and mental health. Rev Bras Enferm. 2021;74(Suppl 5):e20200525. https://doi.org/10.1590/0034-7167-2020-0525

Corresponding author:

Cláudia Mara de Melo Tavares

E-mail: claudiamarauff@gmail.com

EDITOR IN CHIEF: Dulce Barbosa ASSOCIATE EDITOR: Fátima Helena Espírito Santo

Submission: $07-18-2020$

Approval: $12-06-2020$

\begin{abstract}
Objective: to know innovative pedagogical experiences developed by professors in the teaching of psychiatric nursing and mental health in undergraduate nursing courses at public universities in Rio de Janeiro State. Method: based on an ethnomethodological approach, individual semi-structured interviews and document analysis were carried out according to content analysis. Results: despite the heterogeneity in the curriculum distribution of psychiatric nursing's and mental health's knowledge, the themes taught have similarities. The perceptions of innovation are mainly related to interdisciplinary practices and teaching, relational, and care technologies. Innovative teaching practices are focused on the use of active methodologies and collaborative activities. Final considerations: innovating teaching requires creating strategies to teach people how to care for people, valuing human uniqueness. Student participation in health services is the key to the dialogue between knowledge produced in academia and that mobilized in health services.

Descriptors: Education, Nursing; Curriculum; Mental Health; Psychiatric Nursing; Innovation.
\end{abstract}

\section{RESUMO}

Objetivo: conhecer experiências pedagógicas inovadoras desenvolvidas por docentes no ensino da enfermagem psiquiátrica e saúde mental nos cursos de graduação em enfermagem de universidades públicas do estado do Rio de Janeiro. Método: embasada por abordagem etnometodológica, foram realizadas entrevistas individuais semiestruturadas e análise documental, segundo a análise de conteúdo. Resultados: apesar da heterogeneidade na distribuição curricular dos saberes da enfermagem psiquiátrica e saúde mental, os temas lecionados apresentam semelhanças. As percepções de inovação estão principalmente relacionadas a práticas interdisciplinares e uso de tecnologias de ensino, relacionais, de cuidado. As práticas inovadoras de ensino estão voltadas à utilização de metodologias ativas e atividades colaborativas. Considerações finais: inovar o ensino demanda criar estratégias para ensinar gente a cuidar de gente, valorizando a singularidade humana. A participação dos estudantes nos serviços de saúde é a chave para o diálogo entre o conhecimento produzido na academia e o mobilizado nos serviços de saúde.

Descritores: Educação em Enfermagem; Currículo; Saúde Mental; Enfermagem Psiquiátrica; Inovação.

\section{RESUMEN}

Objetivo: conocer experiencias pedagógicas innovadoras desarrolladas por docentes en la enseñanza de enfermería psiquiátrica y salud mental en cursos de pregrado en enfermería en universidades públicas del estado de Rio de Janeiro. Método: con base en un enfoque etnometodológico, se realizaron entrevistas individuales semiestructuradas y análisis de documentos, de acuerdo con el análisis de contenido. Resultados: a pesar de la heterogeneidad en la distribución curricular del conocimiento de enfermería psiquiátrica y salud mental, los temas enseñados presentan similitudes. Las percepciones de innovación están relacionadas principalmente con las prácticas interdisciplinarias y el uso de tecnologías docentes, relacionales y asistenciales. Las prácticas de enseñanza innovadoras se centran en el uso de metodologías activas y actividades colaborativas. Consideraciones finales: innovar en la enseñanza requiere crear estrategias para enseñar a las personas cómo cuidar de las personas, valorando la singularidad humana. La participación de los estudiantes en los servicios de salud es clave para el diálogo entre el conocimiento producido en la academia y el movilizado en los servicios de salud.

Descriptores: Educación en Enfermería; Curriculum; Salud Mental; Enfermería Psiquiátrica; Innovación. 


\section{INTRODUCTION}

The training of nursing professional to work in psychiatric and mental health (MH) dimensions demands efforts to meet the requirements of the current Brazilian National Curriculum Guidelines (DCN - Diretrizes Curriculumes Nacionais), as well as adjust to social, cultural, ethical and care techniques changes valued by the Psychiatric Reform (PR) in Brazil. These efforts need to recognize the innovations already developed in teaching for these dimensions, the appropriate discussion of their principles and results so that they can be effectively shared. To promote significant advances in the nursing profession, it is necessary to establish training objectives based on a free, creative and reflective teaching approach ${ }^{(1)}$. These approaches are expected to provide nurses with knowledge, skills and attitudes consistent with society's expectations for the profession.

In the training of nurses, the challenge proposed by DCN has been to train professionals to consolidate the Unified Health System (SUS - Sistema Único de Saúde) in its article 5, single paragraph ${ }^{(2)}$. Achieving this purpose requires undergraduate nursing courses the ability to articulate professional knowledge and specific health needs with the knowledge developed in different devices in the health network. In this way, nursing training starts to require changes in the teaching process, enabling an expanded analysis of health problems, mastery of new technologies and working methods to solve them. It is necessary to establish innovative teaching-learning strategies that favor dialogue, teamwork, transdisciplinarity, considering formal and non-formal knowledge, considering the skills required in the health work process to construct collective projects ${ }^{(3)}$.

National MH policy offers new ways of seeing and dealing with mental illness. This requires a conceptually different approach to the training of nursing students, making it essential to develop processes of innovation in teaching and professional practice of $\mathrm{MH}$, establishing an overcoming of the hegemonic, iatrogenic asylum paradigm, deinstitutionalization and social inclusion of people with psychological distress. At this point, change in students' behavior and a new dimension in the way of caring are evoked, whose basic premise is subjects' understanding. In this perspective, training nurses requires professors to be able to articulate professional knowledge and specific health needs with that of the entire network of knowledge developed in different devices of the psychosocial care network in the health system. The training of health professionals now requires interdisciplinary teaching programs that enable more integrated analyzes of health problems.

Lucchese $\mathrm{e}^{(4)}$ highlights the mismatch between the teaching and practices of $\mathrm{MH}$ in Brazil, the absence of spaces for discussing the daily routines common to teaching and assistance, the absence of Political Pedagogical Projects (PPP) and common therapeutics and the absence of intertwining between the paradigms of transformative pedagogy and PR. Based on this, it is possible to notice that the current nurse training process is constituted by influences and perspectives of the current public model, but it is not totally detached from the profession's history, impregnated with technical and assistance practices that did not always correspond to the population's real health needs.
Recently, we studied processes of change in nursing education, focusing on the social action of subjects in the construction of institutions, such as SUS. Based on Berger \& Luckmann ${ }^{(5)}$, we understand institutions as concretized human actions and, therefore, they can change. We think that changes in nursing training are introduced through processes of experimentation by professors in their teaching practices. As a group of professors starts to adopt change frequently, an increasing number of people tend to adopt innovations in training and professional practice. Understandings like this point to the importance and relevance of conducting studies on this topic.

\section{OBJECTIVE}

To know innovative pedagogical experiences developed by professors in the teaching of psychiatric nursing and mental health in undergraduate nursing courses at public universities in Rio de Janeiro State.

The specific objectives were: to characterize and discuss the curriculum spaces for innovation in teaching psychiatric nursing and mental health in nursing; to identify innovative experiences in teaching psychiatric nursing and mental health in undergraduate nursing courses at public universities in Rio de Janeiro State; to characterize the contribution of innovations produced to psychiatric nursing (NP) and mental health. This study is part of the Research Project on innovation in the teaching-learning process of NP.

\section{METHODS}

\section{Ethical aspects}

All guidelines pertinent to the research with regard to Resolution 466/2012 were accepted by the Brazilian National Health Council (CNS - Conselho Nacional de Saúde), with the approval of the Research Ethics Committee with Human Beings of Universidade Federal Fluminense. Participants signed an Informed Consent Form, and their anonymity was preserved.

\section{Type of study}

This is a qualitative research of an ethnographic nature, which includes field research, which allows access to the daily practical perspectives of social actors and to documents written by them ${ }^{(6)}$. The present study was analyzed according to the Consolidated Criteria for Reporting Qualitative Research (COREQ) ${ }^{(7)}$.

\section{Methodological procedures}

\section{Study setting}

The study was carried out in nursing schools at a public university (PU) in Rio de Janeiro State.

\section{Data source}

Considering the social basis of the problem investigated, we will resort to the ethnographic perspective, since the study 
focuses on the culture of a certain group, psychiatric nursing (PN) and $\mathrm{MH}$ professors. The study subjects were $14 \mathrm{PN}$ and $\mathrm{MH}$ professors (84.2\% of the total), distributed according to Rio de Janeiro's PU.

\section{Data collection and organization}

In order to identify the experiences of innovating methods and technologies for teaching $\mathrm{PN}$ and $\mathrm{MH}$, the following procedures were adopted: identification of professors through consultation of university web pages and telephone contact with the course coordinator; research in the "Curriculum Lattes" platform, in which the publications of each one was published in scientific journals and research of the course programs. To investigate the pedagogical training of professors referred to innovative practices and the contributions of innovations produced by the studied subjects, we used semi-structured interviews with professors. All interviews covered topics focused on the pedagogical perspective, professional experiences in the $\mathrm{MH}$ field and their influences on teaching practice. The interviews were recorded, transcribed and, following content analysis ${ }^{(8)}$, screened and interpreted according to the following steps: choosing documents; general reading; coding; material clipping; establishment of categories; grouping the units into categories; progressive grouping of categories; inference; interpretation. Effective professors and substitutes in MH of Rio de Janeiro's PU were included in the research; professors who were licensed during the period were excluded.

The research was conducted by a team of researchers, including university professors and undergraduate students properly trained in previous research. There was no relationship or relationship between interviewers and interviewees. Participants were selected on purpose according to the object of the study. They were contacted by email and calls to participate in the research. Participants were informed about the results of the study.

\section{Data analysis}

The data were digitized and treated according to Bardin's thematic analysis ${ }^{(8)}$. Initially, a general reading was undertaken, moving on to data coding; the first categories were established, which were grouped into larger categories. After data treatment ended, interpretation was carried out. The categories and subcategories of analysis that emerged from the data were: Innovative curriculum aspects (content, methodology, bibliography); Teaching innovation meanings for professors in psychiatric nursing and mental health (concept of innovation, concept of technology, learning settings, care perspective); Innovative teaching-learning practices in the undergraduate nursing course (resources, spaces/environments, processes). These categories guided analysis of interviews and documents.

\section{RESULTS}

\section{Innovative curriculum aspects present in psychiatric nursing and mental health}

Analysis of the curriculum programs (provided by professors or coordinators) of subjects related to $\mathrm{PN}$ and $\mathrm{MH}$ in the researched universities revealed that there is no uniformity regarding the workload of these studied subjects. The percentage of hours devoted to teaching $\mathrm{PN}$ and $\mathrm{MH}$ is low, making up an average of $7 \%$ of the total hours of training.

In order to favor visualization and comparison of objective data resulting from documentary assessment, we have systematized the information in Chart 1. In this chart, the courses, the semester in which they are taught, the respective workload of each undergraduate nursing course in Rio de Janeiro's PU can be seen.

Chart 1 - Characterization of psychiatric nursing and mental health courses by institution under study

\begin{tabular}{|c|c|c|c|c|c|}
\hline Institution & $\begin{array}{c}\text { Course } \\
\text { workload }\end{array}$ & $\begin{array}{c}\text { Number of } \\
\text { professors in } \\
\text { the field }\end{array}$ & Course & Semester & $\begin{array}{l}\text { Semester } \\
\text { workload }\end{array}$ \\
\hline \multirow{3}{*}{ A } & \multirow{3}{*}{$\begin{array}{l}4,125 \\
\text { hours }\end{array}$} & \multirow{3}{*}{3 professors } & A1 & $7^{\text {th }}$ & 105 hours \\
\hline & & & A2 & $7_{\text {th }}$ & 90 hours \\
\hline & & & A3 & $7^{\text {th }}$ & 30 hours \\
\hline \multirow{3}{*}{ B } & \multirow{3}{*}{$\begin{array}{l}4,065 \\
\text { hours }\end{array}$} & \multirow{3}{*}{3 professors } & B1 & $5^{\text {th }}$ & 45 hours \\
\hline & & & B2 & $7^{\text {th }}$ & 90 hours \\
\hline & & & B3 & $9^{\text {th }}$ & 150 hours \\
\hline \multirow{4}{*}{ C } & \multirow{4}{*}{$\begin{array}{l}4,500 \\
\text { hours }\end{array}$} & \multirow{4}{*}{5 professors } & C1 & $2^{\text {nd }}$ & 60 hours \\
\hline & & & C2 & $6^{\text {th }}$ & 60 hours \\
\hline & & & C3 & $8^{\text {th }}$ & 250 hours \\
\hline & & & C4 & $9^{\text {th }}$ & 250 hours \\
\hline \multirow{8}{*}{ D } & \multirow{8}{*}{$\begin{array}{l}5,850 \\
\text { hours }\end{array}$} & \multirow{8}{*}{6 professors } & D1 & $1^{\text {st }}$ & 15 hours \\
\hline & & & D2 & $2^{\text {nd }}$ & 30 hours \\
\hline & & & D3 & $3^{\text {rd }}$ & 15 hours \\
\hline & & & D4 & $4^{\text {th }}$ & 30 hours \\
\hline & & & D5 & $6^{\text {th }}$ & 30 hours \\
\hline & & & D6 & $7^{\text {th }}$ & 45 hours \\
\hline & & & D7 & $7^{\text {th }}$ & 112 hours \\
\hline & & & D8 & $8^{\text {th }}$ & 164 hours \\
\hline
\end{tabular}

Chart 2 presents data analysis from the programs of the courses studied. We sought to highlight not the similarities or thematic units between the courses, but the multiplicity and uniqueness of the programs and innovative aspects related to training in $\mathrm{PN}$ and $\mathrm{MH}$. The curriculum elements investigated in this phase were content, bibliography, and methodology. For demonstration purposes, we chose to choose up to two examples for each of the selected curriculum items based on strangeness and/or innovative aspects of the courses.

The teaching programs of the four universities presented many similar themes and approaches, such as interpersonal relationships, individual attention to users of $\mathrm{MH}$ services, $\mathrm{MH}$ policy, and PR. We seek, in the presentation of the chart above, to describe only the singular aspects of the courses, seeking in them the trail of innovation. 
Chart 2 - Innovative aspects present in the elements of mental health courses by institution under study

\begin{tabular}{|c|c|c|c|}
\hline Institution & Content & Methodology & Bibliography \\
\hline A & $\begin{array}{l}\text { - Socially adjusted and maladjusted people. } \\
\text { - Difficulty of integration and work program - the } \\
\text { community vision. }\end{array}$ & $\begin{array}{l}\text { Demonstration of nursing activities during } \\
\text { home visits. }\end{array}$ & $\begin{array}{l}\text { - Related to homosexuality, the } \\
\text { world of crime, deviation and } \\
\text { divergence. }\end{array}$ \\
\hline B & $\begin{array}{l}\text { - Work as a generator of emotional disorders. } \\
\text { - Special themes in Psychiatric Nursing: care for } \\
\text { older adults and children in the community. }\end{array}$ & $\begin{array}{l}\text { - Movie analysis and discussion } \\
\text { - Visits to support units and support groups. } \\
\text { - Use of virtual learning environment. }\end{array}$ & $\begin{array}{l}\text { - Music in human terminality. } \\
\text { - User satisfaction with care in } \\
\text { Mental Health. }\end{array}$ \\
\hline $\mathrm{C}$ & $\begin{array}{l}\text { - Globalization and Mental Health. } \\
\text { - Environmental context of care. }\end{array}$ & $\begin{array}{l}\text { - Esthetic experiments. } \\
\text { - Tutoring in small groups using problem } \\
\text { situations. } \\
\text { - Internships with interdisciplinary } \\
\text { characteristics, operated by the teaching } \\
\text { departments. }\end{array}$ & $\begin{array}{l}\text { - Environmental health. } \\
\text { - Creative imagination. }\end{array}$ \\
\hline $\mathrm{D}$ & $\begin{array}{l}\text { - Identity, sexuality, game - dependency/ } \\
\text { independence. } \\
\text { - Body language. } \\
\text { - Psychosomatics and psychoimmunology. }\end{array}$ & $\begin{array}{l}\text { - Group experiences. } \\
\text { - Group dynamics with actions that increase } \\
\text { quality of life. }\end{array}$ & $\begin{array}{l}\text { - Life encounters. } \\
\text { - Psychosomatic phenomena. }\end{array}$ \\
\hline
\end{tabular}

When analyzing $\mathrm{PN}$ and $\mathrm{MH}$ course programs, we noticed the reduced number of courses and the absence of the expressed content of $\mathrm{MH}$ in institution A. The terms "psychiatry" or "mental health" do not appear in the title of the courses, highlighting the terms-concepts: care, people, rehabilitation processes and simplified diagnosis. Even knowing that the curriculum of this institution is integrated and interdepartmental, we consider a problem the lack of description of the specific contents or titles of the field. At institution D, it is strange that all courses have the same title, distinguishing themselves only by number throughout the course periods. Institution D teaches psychiatry and $\mathrm{MH}$ throughout the course; however, the total workload for teaching $\mathrm{MH}$ is small. In the examined institutional documents, there was no methodological emphasis on the appreciation of active teaching-learning methodologies. Institution $C$ has more recently highlighted this approach, influenced by the development of research on screen.

As for the bibliographies proposed by the courses, it was observed the emphasis given to some current themes, although we consider them insufficient to effectively contemplate an innovative teaching perspective. Analyzing the bibliography with the cultural artefact indicator, we find that they use little innovative base references.

\section{The sense of teaching innovation for psychiatric nursing and mental health professors}

The concept of technological innovation is a first point that deserves to be highlighted. The concept of technology is broad and has been inserted in the context of health for a long time. $\mathrm{MH}$ professors consider the relationship between subjects as technology.

[...] the technological innovation that I do I call soft technology, is a Mehry appellation. I work from the perspective of the relationship between subjects [...]. (D6)

[...] I often use the concept of soft technology when I am going to hold an exhibition and discuss with students what they felt or did not feel... it is about relating to the other, putting oneself in the other's place. (D7)
[...] / use soft technologies, relational and communication are present in my practice. I also work with artistic techniques, manuals... (D12)

Technology is not only a piece of equipment, but also the know-how/operant that gives meaning and reason to the equipment itself, relating directly to the characteristics of the subject - such as capacity and creativity and their actions ${ }^{(9)}$. Soft technologies include relationships such as bond production, reception, management as a way of governing work processes ${ }^{(10)}$. In the $\mathrm{MH}$ field, the use of soft technology as a central axis in the provision of care favors the approximation between professional, user and community, strengthening ties, contributing to patients' autonomy. This approach redirects the nursing work process, meeting the reality of those involved ${ }^{(9)}$. The relationship between technological innovation and workloads depends on several factors, such as the conditions of implementation, the values and subjectivity involved in the action ${ }^{(10)}$.

Another sense of innovation that deserves to be highlighted is related to the challenges of PR for teaching innovation. The PR recommends the reorientation of $\mathrm{MH}$ services, implying resizing the view on the needs of a person with psychological distress ${ }^{(9)}$; re-signification of common sense regarding madness, possibility of coexistence of the mentally ill with society; replacement of the asylum model by the psychosocial perspective of health care ${ }^{(11)}$. For the implementation of these principles, innovations are necessary in several fields, such as legal, sociocultural, ethical, economic and techno-assistance ${ }^{(13)}$.

[...] we prioritize the issue of psychiatric reform. It discusses how to act with the user in the territory, especially in the process of dehospitalization and de-institutionalization. In the internship, we deal with users who are leaving hospital and we try to focus on the care activities that nurses can perform - nursing consultation, home visit, health education. (D2)

We start by talking about the difference between health and mental illness, history of psychiatry and PR. We discussed the new assistive devices, CAPS, therapeutic residency, the "back home" program, making a comparison about what we had in psychiatry and what 
we have today. Conversation about laws, PR impasses and about nurses' therapeutic work. (D6)

In professors' testimonies, it was observed that such principles have been introduced in the theoretical dimension of $\mathrm{MH}$ teaching, although there are some obstacles regarding practical teaching.

[...] we have difficulties in training due to the small workload for MH. (D5)

[...] so, sometimes, we have a small workload, a large class and a field of practice that does not always facilitate, this is hard [...]. (D3)

The time allocated to $\mathrm{MH}$ in the nursing curriculum does not allow the deepening of scientific knowledge on the theme, as well as the practice in the different devices of care for post-retirement $\mathrm{MH}^{(9)}$, which often determines an overload of extra-class activities or even obliges the professor to choose a single $\mathrm{MH}$ service, reducing the breadth of teaching ${ }^{(14)}$.

Another issue concerns the practical learning setting, which demands an adequate structure, since academics will develop perceptions that correspond to the environment in which they are inserted in their practical setting.

[...] insufficient network of services to cover a large number of students and the way the curriculum is structured so that these students can get to know the network. (D7)

[...] a large class and a field of practice with restricted physical space impairs teaching. This is really difficult. (D3)

This perception comes close to the possibility of implementing the care technology learned in theory, leading the relationship between student-care and student-service ${ }^{(14) .}$.The relationship between the large number of students for practical learning and the small physical spaces of the new devices is pointed out as a problem. The restrictions placed by health institutions to receive students in their facilities make the organization of activities in the fields of practice increasingly problematic ${ }^{(9)}$. Additionally, there is a small number of professors in each field, which exacerbates the volume of activities that each develops in the institutions, making the integration of knowledge unfeasible. These aspects have hindered the deeper and more frequent discussion of the course PPP, pedagogical practices and nursing performance ${ }^{(14) .}$

There is a need to problematize aspects of the interface of nursing $\mathrm{DCN}^{(14)}$ with the training process in $\mathrm{PN} / \mathrm{MH}$. It is not enough to point out issues related to content and didactics, changes need to be implemented to ensure meaningful, transformative learning that is appropriate to social and professional demands ${ }^{(16)}$. It is necessary to rethink the training of nurses to work on the new devices, to be prepared to act not only in a specific core of knowledge $\mathrm{e}^{(9)}$, based on knowledge from the collective field of practices $^{(17)}$

[...] / think that there is an important weakness as $\mathrm{MH}$ is only worked on isolated courses within the curriculum [...]. (D13)

[...] the curriculum does not allow the valuation of subjective care; it is a weakness. (D2)
[...] I find more attention in this training the difficulty for us to have recognition in terms of academic curriculum, we need an effective workload, a sufficient number of $\mathrm{MH}$ and psychiatry professors. (D14)

The new care perspective based on integrality translates an internal need for the field of $\mathrm{MH}$, since its object of work involves social relationships, emotional, affective and biological expressions ${ }^{(18)}$. This requires professionals capable of articulating specific knowledge with the entire network of knowledge involved in the health system so that there can be improvements in the population's living conditions. The interviewees pointed out the importance of articulation with the $\mathrm{MH}$ service network to achieve the training objectives.

Many of the professionals working in the network were my undergraduate or residency students. We work in the undergraduate and also in the residency, training nurses specialized in $\mathrm{MH}$ and psychiatry. As here in Rio de Janeiro there are few services that offer graduate education, so somehow I end up contributing to this training of professionals who are in the field today. (D4)

The students note that here in the city the network is very fragile, so they have the exercise of trying to think about what it would be like to make this network talk, the services to interact, but this is a little difficult for them. Service professionals have difficulties in carrying out intersectoral actions [...]. (D2)

[...] today, I am experiencing a very serious problem, the network is closing more and more. Before, I used to go to CAPS with the students, I spent the whole week without a problem, now the students are not wanting there [...] articulated work with the network is fundamental for the training of professionals and for the health team and the population. (D8)

\section{Innovative teaching-learning practices in the undergra- duate nursing course}

The innovation of health practices such as training is highly desired and has generated several public policies so that these new models of teaching and caring are made possible ${ }^{(19)}$. The responses of the interviewed professors highlighted innovation in the $\mathrm{MH}$ area as a basic requirement of PR. Innovative practices, such as welcoming strategies, bonding and affirming citizenship, are carried out so that there is the best possible treatment for individuals in psychological distress.

It was found that, among $\mathrm{PN}$ and $\mathrm{MH}$ professors, the definition of innovation is very broad and without specific specification for teaching in $\mathrm{MH}$. The types of innovation found are based on innovation processes of technologies applied to teaching, such as, for instance, virtual learning environments, and/or experiences with active learning methodologies, influenced by the problematization of ideas and the professor-student interaction throughout the teaching-learning process ${ }^{(20)}$.

[...] I select content through the web. For a particular group, I remember that I referred five or six sites talking about the subject. I divided the class that was very large among the subthemes and then asked, in advance, that they bring some content based on 
internet access. They went to consultation and then we built questions with fundamental aspects of that content and then the groups searched the network for the answers to the questions and each group put together a slide show. At the end of the class, in the last hour of class, we left fifteen minutes for each group to make their presentation, and they created, brought figures and then we made it available to the class. There was the intention to put on a course blog. (D8)

Computer science was highlighted as an ally of teaching innovation. The paradigm shift in information technology, due to its growing expansion, breaks with the idea of thinking about information technology as an isolated science ${ }^{(20)}$ and tending to interdisciplinarity, by encouraging more and more people to use the different areas of knowledge ${ }^{(19)}$.

Some professors describe that the research centers represent a favorable environment for the development of more dynamic, flexible and interactive educational practices, where they can listen to students and exchange experiences with them; a fact that sometimes it is not possible to take place in the classroom due to the limited time to teach a certain subject and the greater number of students ${ }^{(20)}$.

[...] what is very positive for the innovative process are the research groups. In research groups, I bring my nursing students together with pharmacy students with engineering students and others. For instance, I call a professor of biostatistics and another of physical education. We get together, discuss a topic, people expose their ideas and move on from there, we use knowledge to take a step into the future [...]. (D9)

It is important to highlight the limitation of this device to reach critical mass, since a limited number of undergraduate students, in general PIBIC scholarship holders, of extension or monitors, participate in professors' research centers. However, we cannot lose sight of the fact that this strategy could increase student participation, constituting a form of innovation when educating through research, as demonstrated by Demo(22).

Interdisciplinarity was pointed out as another way to innovate. As the disciplinary spaces defined in the curricula are transcended, the knowledge gains the necessary fluidity to better approach the daily activities.

[...] you form a group and then the courses deconstruct themselves because in fact you need an interdisciplinary group that buys the same idea, that wants to invest in that [...] to have an innovative teaching project you cannot be closed in that context of your profession, but you have to integrate with other professionals [...]. (D9)

Assessment was an important axis in the perception of the innovation process. When approaching assessment of innovative activities, professors emphasized issues related to the participation and involvement of students with their learning.

lassess through the development of each one in their perception process as a social actor in health care [...] my assessment is in the sense that I need students to mature about their reality and their role there [...] it occurs when I begin to realize that they, regardless of knowledge or technique, begin to show themselves as a professional who seeks to break free. That's where I feel it worked. (D6)

A teaching-learning assessment process is presented that runs through the individual sphere, revealing itself full of subjectivity. Araújo \& Almeida ${ }^{(23)}$ point out some essential characteristics to the learning assessment process, such as being a continuous, permanent, and monitoring action. In this sense, the intention of changes in assessment by professors was verified, with actions developed guided by humanistic pedagogical practices ${ }^{(20)}$.

Regarding the teaching-service interaction to enhance the change processes, there is a little interaction between the academy and the innovation processes in the service, with little participation of professors in the proposed innovative activities, even though they involve students. Teaching-service integration has historically been recognized as a problem for advancing and innovating health services. The articulation process was enhanced by the ministerial inducing policies through the Brazilian National Program for Reorienting Professional Training in Health (Pró-Saúde-Programa Nacional de Reorientação da Formação Profissional em Saúde) and the Education through Work for Health Program (PET-Saúde - Programa de Educação pelo Trabalho para a Saúde), implemented since 2006. Such programs aim to promote training rearrangement in the health field, aiming at the integration of education and work in health, strengthening the perspective of teaching-service integration ${ }^{(24)}$.

\section{DISCUSSION}

We emphasize that consolidating innovative practices demands professionals who are willing to act differently from the traditional one, facing difficulties implementing new proposals for professional action, thinking, first of all, of the well-being of subjects who need care. In this sense, it is important to think according to a humanistic framework in nursing to be able to rescue subjects' subjectivity and cause a change from the clinical look to a comprehensive look, which involves interaction and dialogue ${ }^{(25)}$.

Nursing education in $\mathrm{MH}$ needs to take into account the change/ innovation needs foreseen in the legal field, highlighting: Law 8080/90, which makes SUS responsible for organizing a health training system covering all levels of education, the national management is responsible for promoting the articulation with the educational and supervisory bodies of professional practice as well as with representative entities for training human resources in health ${ }^{(20)}$; CNE/CES Resolution 03 of 07/11/2011 (DCN)(16), which proposes the formation of critical, reflective professionals, inserted in the historical-social context, capable of intervening in health problems; Law 10.216 of 06/04/2001, which deals with the protection of people with mental disorders and redirects assistance to community-based services ${ }^{(26)}$.

The entry of students in extra-hospital psychosocial care devices makes it possible to understand service users as subjects inserted in a social environment ${ }^{(27)}$. In their responses, professors highlighted that their professor activities, whether inside or outside the classroom, represent fundamental moments for students to move towards professional and personal preparation. Such experiences of training in $\mathrm{MH}$ prove to be a complex process due 
to the very structure of SUS. The fields of professional activity are very wide, spanning several sectors and networks; therefore, it is necessary to recognize the dependence on other fields of activity and knowledge, such as philosophy, politics, history, arts, among others ${ }^{(18)}$.

$\mathrm{PN}$ and $\mathrm{MH}$ professors understand teaching innovation as the introduction of something new in their practices, being something that breaks with the traditional teaching model. In this research, it was observed that many professors develop teaching practices based on principles advocated by SUS, on the new DCN and on theoretical parameters established for creative and innovative teaching practices. However, the commitment to strengthening SUS and PR principles demands innovative teaching practices and not just a change in theoretical perspective, requiring developing partnerships and academic experiences of permanent integration with health services, a challenge that persists despite the public policies engendered.

Thus, for professionals to reach and guide their practices through innovative proposals, it is necessary to redirect nursing training. This requires PPPs with innovative perspectives and institutions that distinguish, value and support innovative professors, who are key figures in the training process. In the academic context studied, innovation initiatives are mediated by look appreciation - professors - when recognizing students' needs and teaching them to recognize patients' emotional needs. It is about educating sensitivity by example. To innovate teaching, it is necessary to create ways, technologies, strategies to teach people how to take care of people, valuing human uniqueness. Innovative teaching in $\mathrm{PN}$ and $\mathrm{MH}$ is to recognize, in simple, yet powerful gestures of knowledge and commitment to life, what is fundamental to people's health.

Educational practices pointed out by participants include new information and communication technologies; active methodologies; new forms of communication aiming at professor-student interaction; active teaching through research groups. On the other hand, the main difficulties pointed out by professors to innovate teaching practice were: (1) difficulty in teaching dialogue with health services; (2) lack of access to problem situations faced in the daily routine of $\mathrm{MH}$ services; (3) difficulty in strengthening an expanded worldview about the condition of $\mathrm{MH}$ due to the reduced workload in $\mathrm{PN}$ and $\mathrm{MH}$; (4) lack of dialogue with professionals from other fields, hindering teamwork and interdisciplinary knowledge.

\section{Study limitations}

It is understood that the sample of informants is restricted to only one state. Another limitation is that the data express only the teaching perspective. The expansion of this universe could favor the emergence of a greater diversity of data.

\section{Contributions to nursing, health, and public policy}

The results of this research can contribute to broaden the understanding of innovation processes in teaching $\mathrm{PN}$ and $\mathrm{MH}, \mathrm{a}$ necessary action to face the changes concerning the PR process in Brazil and the requirements of the current DCN for nursing training.

\section{FINAL CONSIDERATIONS}

The results make it possible to understand that there is a theoretical effort by professors to train for SUS, guided by PR's perspective; student participation in health services is the key to the dialogue between knowledge produced in academia and that mobilized within health services. Students are an important link to be considered in the innovation chain, providing a means of sustainability, adhesion and participation in the process of changing professional practice. Their look and concerns, combined with their fearlessness for change, allow us to launch a new interpretation of the problems present in the daily lives of health services.

Based on the findings of this study, we suggest: (1) that isolated innovation initiatives by academia and health services be encouraged and institutionally supported, taken as a first step towards innovation; (2) to obtain interinstitutional consensus on the knowledge specific to the MH field, considering three dimensions, such as transversal knowledge, specificity and specialty, pointing out ways for the new DCNs; (3) to encourage using active methodologies for training in line with current social and health service needs. Moreover, the importance of training students to work in multidisciplinary contexts is emphasized.

\section{FUNDING}

CNPq - Conselho Nacional de Desenvolvimento Científico e Tecnológico.

CAPES - Coordenação de Aperfeiçoamento de Pessoal de Nível Superior.

\section{REFERENCES}

1. Fontes W, Leadebal O, Ferreira J. Competences for the application of the nursing process: self-evaluation of the students that are completing the requirements for the undergraduation course. Rev Rene [Internet]. 2010[cited 2019 Nov 4];11(3):86-94. Available from: http://www.revistarene.ufc.br/revista/index.php/revista/article/view/399/pdf

2. Ministério da Educação e Cultura (BR). Conselho Nacional de Educação. Diretrizes Curriculares Nacionais dos Cursos de Graduação em Enfermagem, Medicina e Nutrição. Parecer CNE/CES 1.133. [Internet]. 2001 [cited 2019 Sep 12]. Available from: http://portal.mec.gov.br/dmdocuments/ces1133.pdf

3. Machado M, Monteiro E, Queiroz D, Vieira N, Barroso M. Integrality, health professional education, health education and SUS proposals: a conceptual review. Cienc Saude Colet. 2007;12(2):335-342. https://doi.org/10.1590/S1413-81232007000200009

4. Lucchese R. A enfermagem psiquiátrica e saúde mental: a necessária constituição de competências na formação e na prática do enfermeiro [Tese] [Internet]. Escola de enfermagem da USP; 2005 [cited 2019 Sep 12]. https://doi.org/10.11606/T.83.2005.tde-17112006-111354 
5. Berger P, Luckmann T. A construção social da realidade: tratado de sociologia do conhecimento. Rio de Janeiro: Vozes; 2004.

6. Coulon A. Etnometodologia e educação. Petrópolis: Vozes; 1995.

7. Tong A, Sainsbury P, Craig J. Consolidated criteria for reporting qualitative research (COREQ): a 32-item checklist for interviews and focus groups. Int J Qual Health Care. 2007;19(6):349-57. https://doi.org/10.1093/intqhc/mzm042

8. Bardin L. Análise de conteúdo. Ed. revista e ampliada. Lisboa: Edições 70; 2011.

9. Tavares CMM, Gama LN, Paiva LM, Lima TO, Silveira PG. Innovation on Teacher Perception in Mental Health Education. IN: $7{ }^{\circ}$ congresso Iberoamericano de Investigação Qualitativa, 2015, Fortaleza. Atas - Investigação Qualitativa em Saúde [Internet]. 2015 [cited 2019 Sep 12] p. 247-250. Available from: https://proceedings.ciaiq.org/index.php/ciaiq2015/article/download/57/55

10. Merhy EE. Cartografia do trabalho vivo. 3.ed. São Paulo: Hucitec; 2007.

11. Pires DEP, Bertoncini JH, Trindade LL, Matos E, Azambuja E, Borges AMF. Technological innovation and healthcare professionals' workloads: an ambiguous relationship. Rev Gaúcha Enferm. 2012;33(1):157-68. https://doi.org/10.1590/S1983-14472012000100021

12. Rodrigues J, Pinho LB, Spricigo JS, Santos SMA. Use of creativity and technology in teaching the crisis in mental health and psychiatric nursing. SMAD, Rev Eletrôn Saúde Mental Alcool Drog. [Internet]. 2010 [cited 2020 Jan 10];6(1):1-15. Available from: http://pepsic.bvsalud. org/pdf/smad/v6n1/11.pdf

13. Villela JC. O ensino de saúde mental na graduação de enfermagem [Dissertação]. Universidade Federal Paraná; 2008.

14. Soares AN, Gazzinelli MF, Souza V, Araújo LHL. The Role Playing Game (RPG) as a pedagogical strategy in the training of the nurse: an experience report on the creation of a game. Texto Contexto Enferm [Internet]. 2015 [cited 2020 Mar 23];24(2):600-8. Available from: https://www.scielo.br/pdf/tce/v24n2/0104-0707-tce-24-02-00600.pdf

15. Ministério da Educação e Cultura (BR). Conselho Nacional de Educação. Resolução CNE/CES n.3 de 2001. Institui as Diretrizes Curriculares Nacionais dos Cursos de Graduação em Enfermagem, Medicina e Nutrição[Internet]. 7 de novembro de 2001 [cited 2019 Nov 4]. Available from: http://portal.mec.gov.br/cne/arquivos/pdf/CES03.pdf

16. Fernandes JD, Sadigursky D, Silva RMO, Amorim AB, Teixeira GAS, Araújo MCF. Teaching psychiatric nursing/mental health: its interface with the Brazilian Psychiatric Reform and national curriculum guidelines. Rev Esc Enferm USP. 2009;43(4):962-8. https://doi.org/10.1590/ S0080-62342009000400031

17. Vargas D, Oliveira MAF, Duarte FAB. Psychosocial care Center for Alcohol and Drugs (CAPS ad): nursing insertion and practices in São Paulo City, Brazil. Rev Latino-Am Enferm. 2011;19(1):115-22. https://doi.org/10.1590/S0104-11692011000100016

18. Tavares $\mathrm{CMM}$. Interdisciplinarity as requisite for the formation of the psychiatric nurse in the perspective of psycho-social care. Texto Contexto Enferm. 2005;14(3):403-10. https://doi.org/10.1590/S0104-07072005000300012

19. Pereira WR, Tavares CMM. Pedagogical practices in nursing teaching: a study from the perspective of institutional analysis. Rev Esc Enferm USP. 2010;44(4):1077-84. https://doi.org/10.1590/S0104-07072005000300012

20. Alvarenga CM. Inovações no processo de ensino-aprendizagem de Enfermagem da Universidade Federal Fluminense [Internet]. Universidade Federal Fluminense, 2014[cited 2019 Nov 4]. 68 f. Available from: https://app.uff.br/riuff/bitstream/1/4820/1/TCC\%20 Cynthia\%20Medeiros\%20Alvarenga.pdf

21. Corradi MI, Silva SH, Scalabrin EE. Virtual objects to support the teaching-learning process of physical examination in nursing. Acta Paul Enferm. 2011;24(3):348-53. https://doi.org/10.1590/S0103-21002011000300007

22. Demo P. Educar pela pesquisa. Campinas: Autores Associados; 1996.

23. Araújo CMM, Almeida SFC. Psicologia escolar institucional: desenvolvendo competências para uma atuação relacional. In: Almeida SFC (Org.). Psicologia escolar: ética e competências na formação e atuação profissional. Campinas: Alínea; 2003.

24. Gonçalves CNS, Corrêa AB, Simon G. Teaching-service integration in the voice of healthcare professionals. Rev Enferm UFPE [Internet]. 2014 [cited 2020 Feb 4];8(6):678-86. Available from: https://periodicos.ufpe.br/revistas/revistaenfermagem/article/view/13641

25. Almeida ANS. Cuidado clínico de enfermagem em saúde mental: contribuições da psicanálise para uma clínica do sujeito [Dissertação]. Universidade Estadual do Ceará; 2009.

26. Ministério da Saúde (BR). Lei 10.216, de 6 de abril de 2001. Dispõe sobre a proteção e direitos das pessoas portadoras de transtornos mentais e redireciona o modelo de assistência em saúde mental [Internet]. 2001 [cited 2019 Sep 12]. Available from: http://www.saude. mt.gov.br/upload/documento/145/lei-10216-[145-081010-SES-MT].pdf.

27. Soares AN, Silveira BV, Reinaldo AMS. Mental health services and their relation with nursing education. Rev RENE [Internet]. 2010 [cited 2020 Jan 16];11(3):47-56. Available from: http://www.revistarene.ufc.br/revista/index.php/revista/article/view/394 